\title{
SAFE HAVEN INSTRUMENTS - A COMPARISON BETWEEN THE GLOBAL FINANCIAL CRISIS AND THE COVID-19 PANDEMIC
}

\author{
Karolina Siemaszkiewicz \\ Poznan University of Economics and Business, Poznan, Poland \\ Department of Applied Mathematics \\ e-mail: karolina.siemaszkiewicz@ue.poznan.pl
}

ORCID: 0000-0001-8244-2854

\section{(C) 2021 Karolina Siemaszkiewicz}

This work is licensed under the Creative Commons Attribution-ShareAlike 4.0 International License. To view a copy of this license, visit http://creativecommons.org/licenses/by-sa/4.0/

Quote as: Siemaszkiewicz, K. (2021). Safe haven instruments - a comparison between the global financial crisis and the COVID-19 pandemic. Econometrics. Ekonometria. Advances in Applied Data Analysis, 25(4).

DOI: 10.15611/eada.2021.4.01

JEL Classification: C10, C32, C58, C6, G11

\begin{abstract}
During the Global Financial Crisis (GFC) of 2008 and the COVID-19 pandemic, financial markets have e touched their lowest levels. This paper tried to compare the performance of safe haven assets during the Global Financial Crisis and the COVID-19 pandemic in such countries as Germany, Great Britain, France, Spain, Italy, and Poland. The author investigated the dynamic relations between gold, silver, the US Dollar Index, the Swiss Franc Index, soybean commodity futures and corn commodity futures. The study estimated the DCC or CCC models to compare the dynamic relation between the above-mentioned stock markets and financial instruments. The results showed that only gold could protect investors from stock market losses during both crises. During the GFC, gold, the USD Index, the Swiss Franc Index in almost all the considered countries could be identified as safe haven instruments. Surprisingly, the Swiss Franc Index acted as a safe haven instrument during the GFC but not during the COVID-19 pandemic.
\end{abstract}

Keywords: safe haven instruments, Global Financial Crisis, COVID-19 pandemic, gold, dynamic correlation.

\section{Introduction}

During the Global Financial Crisis of 2008 and the COVID-19 pandemic, the financial markets have touched their lowest levels. During the COVID-19 pandemic, the US stock markets experienced their worst turmoil since the 1930s; for example, the 
S\&P 50 suffered a one-third drop from December 2019 until March 2020. The FTSE 100 experienced an unexpected drop of $24.80 \%$ in value in the first quarter of 2020 (The Guardian, 2020). Most of the G7 countries saw the same level of drops in the value of stock indices from December 2019 (Bloomberg, 2020).

On 20 April 2020, crude oil futures for the West Texas Intermediate (WTI), the US oil benchmark, closed at $-\$ 37.63$ per barrel, which was an unusual incident with a deep influence on policymakers and practitioners.

One has to remember that the conduct of the current crisis is different than during the Global Financial Crisis. We are coping with great uncertainty as to when the virus might be fully contained, while financial markets are expecting to see more troubles (Godwell, 2020). The need to search for safe haven assets has arisen for both practitioners and researchers.

Traditionally, gold (Baur and Lucey, 2010; Baur and McDermott, 2010; Hiller, Draper, and Faff, 2006; Pullen, Benson, and Faff, 2014), and currencies such as the US dollar and the Swiss franc (Grisse and Nitschka, 2015; Kaul and Sapp, 2006; Ranaldo and Soderlind, 2010) act as safe havens during periods of stock market turmoil. The question is: are traditional assets that were safe havens during the Global Financial Crisis (GFC) still protecting investments during the current COVID-19 pandemic?

Numerous studies examined the impact of COVID-19 on the financial markets and financial assets (see Al-Awadhi, Al-Saifi, Al-Awadhi, and Alhamadi, 2020; Baker et al., 2020; Corbet, Larkin, and Lucey, 2020; Ramelli and Wagner, 2020; Zhang, Hu, and Ji, 2020). For instance, Baker et al. (2020), Al-Awadhi et al. (2020), and Zhang et al. (2020) found a significant negative impact of COVID-19 on the stock markets.

Gold has been considered a safe haven instrument because of its historical role as natural money or a store of value (Bouri, Shahzad, Roubaud, Kristoufek, and Lucey, 2020). Baur and McDermont (2010) confirmed that gold acted as a hedge and a safe haven for major European and US stock markets, but not for other markets. Beckmann, Berger, and Czudaj (2015) indicated that gold has served as a hedge and an effective safe haven. Hood and Malik (2013) suggested that gold acts as a weak safe haven and strong hedge asset in the US stock markets. Lucey and Li (2015) found out that the strength of gold being a safe haven changes over time.

Moreover, currencies and commodities can also offer a safe haven role in financial markets. Ranaldo and Soderlind (2010) suggested that the Swiss franc and Japanese yen exhibited safe haven properties during a crisis period. Grisse and Nitschka (2015) suggested that the Swiss franc exchange rate can act as a safe haven currency in some cases. Bour et al. (2020) showed that the commodity index is a weak safe haven for some stock indices. Commodities, such as crude oil (Xia, Ji, Zhang, and Han, 2019) and food commodities (like soybeans) have behaved quite differently since the 2008 Global Financial Crisis (Wu, Zhao, Ji, and Zhang, 2020).

This paper tried to compare the performance of safe haven assets during the Global Financial Crisis and COVID-19 pandemic in such European countries as Germany, Great Britain, France, Spain, Italy, and Poland. The author investigated the dynamic 
relation between the most popular instruments such as: gold, silver, the US Dollar Index, the Swiss Franc Index, soybean commodity futures, and corn commodity futures. The study estimated the DCC and CCC models to compare the dynamic relation between the above-mentioned stock markets and financial instruments.

\section{Methodology and data}

The research analysis was carried out on the main stock exchanges indices, namely DAX - Germany, FTSE250 - Great Britain, CAC40 - France, IBEX35 - Spain, FTSE MIB - Italy, and WIG - Poland, as well as gold, silver, the US Dollar Index, the Swiss Franc Index, soybean commodity futures and corn commodity futures. The author considered three periods: the whole sample is from 01.01.2007 to 31.03.2021, and the subsample for the Global Financial Crisis is from 01.09.2008 to 31.08.2009, while the subsample for the COVID-19 pandemic is from 03.02.2020-31.03.2021. The metals' rates from the Thomson Reuters database are given in US dollars (continuous futures series), while the other data come from the web-portal stooq.pl.

Table 1 presents descriptive statistics for the rates of returns series on gold, silver, the USD Index, the Swiss Franc Index, soybean and corn futures, and stock exchanges indices: DAX, FTSE250, CAC40, IBEX35, FTSE MIB, and WIG for all the considered periods. For the whole sample the mean value was close to zero, and in two cases it was negative, and for the other ten instruments, positive. Volatility measured by standard deviations was highest for silver and corn. The skewness is highest for the Swiss Franc Index, and only for that instrument was it positive. In other cases it was negative, which indicates a long-left tail of the empirical distribution of returns. Surprisingly, the kurtosis was high for the Swiss Franc Index, which might be caused by such a long time of observation.

Figure 1 shows that at the end of the considered period one can obtain the highest value for investment in gold. Additionally, one can observe drops in the value of the DAX Index at the beginning of the September 2008 and at the beginning of February 2020.

Baur and Lucey (2010) defined the requirements to distinguish when an asset can act as a diversifier, hedge, and safe haven. To qualify as a safe haven asset, an instrument must be able to keep or increase in value in case of market downturns. Statistically, the returns from a safe haven asset should be uncorrelated or negatively correlated with the returns of other assets during a crisis period. 
Table 1. Descriptive statistics for the rates of return series on gold, silver, USD Index, Swiss Franc Index, soybean, corn, and stock exchange indices from Germany, Great Britain, France, Spain, Italy, Poland, for the considered periods

\begin{tabular}{|c|c|c|c|c|c|c|}
\hline 01.01.2007- 31.03.2021 & Minimum & Maximum & Mean & $\begin{array}{l}\text { Standard } \\
\text { deviation }\end{array}$ & Skewness & Kurtosis \\
\hline GOLD & -6.6617 & 9.2347 & 0.0266 & 0.9949 & -0.0126 & 6.9540 \\
\hline SILVER & $-\mathbf{1 7 . 0 5 8 7}$ & 9.7856 & 0.0166 & 1.7749 & -0.6933 & 8.9457 \\
\hline USD INDEX & -3.3057 & 2.5978 & 0.0032 & 0.4890 & -0.0154 & 2.4902 \\
\hline SWISSFR INDEX & -8.4649 & $\mathbf{1 7 . 2 9 2 0}$ & 0.0114 & 0.5860 & 6.0781 & 219.5320 \\
\hline SOYBEAN & -13.4128 & 7.5874 & 0.0202 & 1.4813 & -0.6219 & 5.7537 \\
\hline CORN & -13.1563 & 8.7431 & 0.0115 & 1.7703 & -0.2365 & 3.1722 \\
\hline DAX & -8.9808 & 10.7975 & 0.0219 & 1.3984 & -0.1193 & 6.8018 \\
\hline FTSE250 & -9.8202 & 8.0388 & 0.0174 & 1.1699 & -0.5281 & 6.9380 \\
\hline CAC40 & -13.0983 & 10.5946 & 0.0017 & 1.4306 & -0.2643 & 8.1935 \\
\hline IBEX35 & -15.1512 & 13.4836 & -0.0142 & 1.5245 & -0.3552 & 9.5137 \\
\hline FTSE MIB & -18.5411 & 10.8742 & -0.0144 & 1.6428 & -0.6505 & 9.3601 \\
\hline WIG & -9.8880 & 6.1919 & 0.0034 & 1.2148 & -0.6115 & 5.6852 \\
\hline \multicolumn{7}{|c|}{ 01.09.2008-31.08.2009 } \\
\hline GOLD & -6.6617 & 9.2347 & 0.0536 & 1.7074 & 0.4932 & 4.5436 \\
\hline SILVER & -12.3914 & 9.7855 & 0.0308 & 2.6320 & -0.0020 & 2.8762 \\
\hline USD INDEX & -3.3057 & 2.3648 & 0.0035 & 0.8524 & -0.3023 & 0.7484 \\
\hline SWISSFR INDEX & -3.1388 & 3.9284 & 0.0284 & 0.8150 & 0.0713 & 3.1749 \\
\hline SOYBEAN & -13.4128 & 7.5873 & -0.1083 & 2.5479 & -0.8004 & 3.0085 \\
\hline CORN & -7.9539 & 7.5577 & -0.2107 & 2.7264 & -0.2130 & 0.5188 \\
\hline DAX & -7.3355 & 10.7974 & -0.0620 & 2.5711 & 0.4087 & 3.0374 \\
\hline FTSE250 & -6.7347 & 7.4621 & -0.0249 & 2.0688 & -0.1813 & 1.0569 \\
\hline CAC40 & -9.4715 & 10.5945 & -0.0777 & 2.6322 & 0.2613 & 2.9211 \\
\hline IBEX35 & -9.5858 & 10.1176 & -0.0109 & 2.4852 & 0.0796 & 2.8252 \\
\hline FTSE MIB & -8.5990 & 10.8742 & -0.0959 & 2.7488 & 0.1176 & 1.8232 \\
\hline WIG & -8.2888 & 6.08374 & -0.0426 & 2.2345 & -0.2778 & 0.9249 \\
\hline \multicolumn{7}{|c|}{ 03.02.2020-31.03.2021 } \\
\hline GOLD & -5.1139 & 4.9613 & 0.0248 & 1.2375 & -0.3786 & 2.5781 \\
\hline SILVER & -16.0804 & 8.2430 & 0.1086 & 2.7964 & -0.9697 & 6.2273 \\
\hline USD INDEX & -1.5405 & 2.0103 & -0.0173 & 0.4496 & 0.5988 & 2.7824 \\
\hline SWISSFR INDEX & -1.3167 & 1.3351 & -0.0019 & 0.3622 & 0.1015 & 0.7976 \\
\hline SOYBEAN & -4.3631 & 4.9947 & 0.1662 & 1.1106 & -0.0417 & 2.4171 \\
\hline CORN & -4.6361 & 4.9539 & 0.1342 & 1.3891 & 0.0546 & 1.1747 \\
\hline DAX & -8.9807 & 7.9433 & 0.0475 & 1.9857 & -0.4775 & 4.7943 \\
\hline FTSE250 & -9.8201 & 8.0387 & 0.0056 & 1.7971 & -0.7170 & 6.5761 \\
\hline CAC40 & -13.0983 & 8.0560 & 0.0089 & 1.9313 & -1.2145 & 9.8059 \\
\hline IBEX35 & -15.1512 & 8.2252 & -0.0343 & 2.0424 & -1.3768 & 12.0989 \\
\hline FTSE MIB & -18.5411 & 8.5494 & 0.0166 & 2.1152 & -2.7627 & 23.3959 \\
\hline WIG & -9.8880 & 6.1919 & 0.0089 & 1.6781 & -1.0814 & 6.2789 \\
\hline
\end{tabular}

Source: own calculations. 


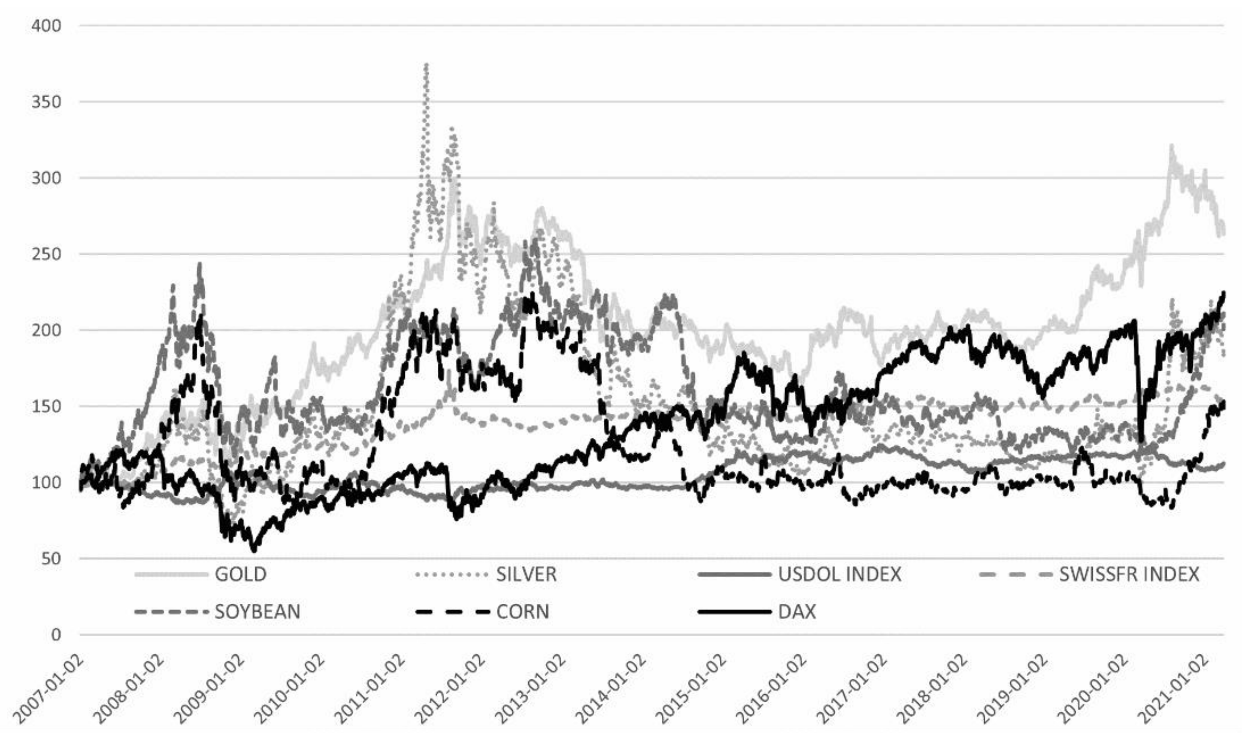

Fig. 1. Gold, silver, USD Index, Swiss Franc Index, soybean, corn, and DAX normalized quotations during 01.01.2007-31.03.2021

Source: own elaboration.

\subsection{Dynamic conditional correlation (DCC) and Constant conditional correlation (CCC)}

Let $Y_{t}=\left(y_{1, t}, \ldots, y_{k, t}\right)$ be the $k$-sized vector of observation at time t. The total number of observations is $n \in \mathbb{N}$. Let us assume that $E_{t-1}\left[\varepsilon_{i, t}\right]=0$ and $E_{t-1}\left[\varepsilon_{i, t}, \varepsilon_{i, t}^{\prime}\right]=H_{t}$. The dynamic conditional correlation model of Engle (2002) reads:

$$
\begin{gathered}
Y_{t}=\mu_{t}+\varepsilon_{t}, \text { with } \varepsilon_{t}=\boldsymbol{H}_{t}^{1 / 2} \mathbf{z}_{t}, \\
\boldsymbol{H}_{t}=\boldsymbol{D}_{t} \boldsymbol{R}_{t} \boldsymbol{D}_{t}, \\
\boldsymbol{D}_{t}=\operatorname{diag}\left(\sqrt{h_{11, t}}, \ldots, \sqrt{h_{k k, t}}\right),
\end{gathered}
$$

where $\mu_{t}$ is the $k$-dimensional conditional mean structure, $\boldsymbol{H}_{t}$ denotes the $(k \times k)-$ sized conditional variance matrix, $\mathbf{z}_{t}$ is a $k$-dimensional vector of independent and identically distributed random variables with zero mean and unit variance, $\boldsymbol{R}_{t}$ is the dynamic correlation matrix of size $(k \times k)$ from which one obtains the time-varying correlation coefficient estimates, and $\boldsymbol{D}_{t}$ is a diagonal matrix of conditional standard deviations of $\varepsilon_{t}$. Assuming $\mathbf{z}_{t} \sim S t-t_{v}\left(0, I_{k}\right)$, let $\xi_{i, t}$ denote the standardised residual 
with respect to the idiosyncratic volatility given as $\xi_{i, t}=\varepsilon_{i, t} / \sqrt{h_{i i, t}}$. The dynamic correlation matrix then decomposes to:

$$
\boldsymbol{R}_{t}=\left(\operatorname{diag} \boldsymbol{Q}_{t}\right)^{-1 / 2} \boldsymbol{Q}_{t}\left(\operatorname{diag} \boldsymbol{Q}_{t}\right)^{-1 / 2},
$$

where $\boldsymbol{Q}_{t}$ denotes the covariance matrix of the standardized residuals $\xi_{t}=$ $\left(\xi_{1, t}, \ldots, \xi_{k, t}\right)$. Engle (2002) introduced a GARCH $(1,1)$-like structure on the elements of $\boldsymbol{Q}_{t}=\left[q_{i j, t}\right]_{i, j=1}^{k, k}$ with:

$$
\begin{aligned}
q_{i j, t}:= & \bar{\rho}_{i j}+\alpha\left(\xi_{i, t-1} \xi_{j, t-1}-\bar{\rho}_{i j}\right)+\beta\left(q_{i j, t-1}-\bar{\rho}_{i j}\right)= \\
& =\bar{\rho}_{i j}(1-\alpha-\beta)+\alpha \xi_{i, t-1} \xi_{j, t-1}+\beta q_{i j, t-1},
\end{aligned}
$$

which is mean reverting as long as $\alpha+\beta<1$ and where $\bar{\rho}_{i j}$ is the unconditional expectation of $q_{i j, t}$ with $\bar{\rho}_{i i}=1$ for all $i=1, \ldots, k$. An estimator for the dynamic correlation is then obtained by calculating:

$$
\begin{aligned}
& \rho_{i j, t}=\frac{q_{i j, t}}{\sqrt{q_{i i, t} q_{j j, t}}} \\
& =\frac{\bar{\rho}_{i j}(1-\alpha-\beta)+\alpha \xi_{i, t-1} \xi_{j, t-1}+\beta q_{i j, t-1}}{\sqrt{1-\alpha-\beta+\alpha \xi_{i, t-1}^{2}+\beta q_{i i, t-1}} \sqrt{1-\alpha-\beta+\alpha \xi_{j, t-1}^{2}+\beta q_{j j, t-1}}} .
\end{aligned}
$$

The difference between the DCC and CCC models is in equation (2), where $\boldsymbol{H}_{t}$ is defined:

$$
\boldsymbol{H}_{t}=\boldsymbol{D}_{t} \boldsymbol{R} \boldsymbol{D}_{t},
$$

where $\boldsymbol{H}_{t}$ is the conditional variance matrix and $\boldsymbol{R}$ is the constant conditional correlation matrix of the process $\varepsilon_{t}$.

Vector GARCH $(p, q)$ process of $\varepsilon_{t}$ is defined as follows (Nakatani and Terasvirta, 2009):

$$
\boldsymbol{h}_{t}=\boldsymbol{a}_{0}+\sum_{i=1}^{q} \boldsymbol{A}_{i} \varepsilon_{t-1}^{(2)}+\sum_{j=1}^{p} \boldsymbol{B}_{j} h_{t-j},
$$

where $\varepsilon_{t-1}^{(2)}=\left(\varepsilon_{1, t}^{2}, \ldots, \varepsilon_{N, t}^{2}\right)^{\prime}, \boldsymbol{a}_{0}$ is a $k$-dimensional vector, and $\boldsymbol{A}_{i}$ and $\boldsymbol{B}_{j}$ are $(k \times k)$ matrices with elements such $h_{i i, t}$ in $\boldsymbol{h}_{t}$ are positive for all $t$.

Equations (1), (2), (8) jointly define the $k$-dimensional CCC-GARCH (p, q) model if $\boldsymbol{A}_{i}$ and $\boldsymbol{B}_{j}$ are diagonal for all $i$ and $j$.

\section{Results and discussion}

This section presents the research results obtained with the use of the methodology mentioned above on the markets of Germany, Great Britain, France, Spain, Italy, and 
Poland. The study considered three periods: the whole sample from 01.01.2007 to 31.03.2021, the subsample for the Global Financial Crisis from 01.09.2008 to 31.08.2009, and the subsample for the COVID-19 pandemic from 03.02.2020-31.03.2021. The calculations of the DCC-GARCH and CCC-GARCH model parameters were made using the professional program OxMetrics by J.A. Doornik.

Table 2. The parameters of the DCC or CCC models of pairwise synchronized return data of the chosen instrument and stock exchange index from Germany for the considered periods. Robust standard errors are available upon request

\begin{tabular}{|c|c|c|c|c|}
\hline \multirow{2}{*}{ DAX } & \multicolumn{4}{|c|}{$01.01 .2007-31.03 .2021$} \\
\hline & $\bar{\rho}$ & $\alpha$ & $\beta$ & $v$ \\
\hline Gold & 0.454155 & 0.314694 & 0.684698 & 19.414306 \\
\hline Silver & 0.191829 & 0.345218 & 0.653780 & 20.470459 \\
\hline USD Index & -0.337291 & 0.304709 & 0.694764 & 25.742956 \\
\hline SwissFr Index & 0.764854 & 0.305671 & 0.693223 & 21.815109 \\
\hline Soybean & 0.425076 & 0.349115 & 0.649589 & 18.463040 \\
\hline \multirow{3}{*}{ Corn } & 0.391807 & 0.369584 & 0.628002 & 18.317157 \\
\hline & \multicolumn{4}{|c|}{ 01.09.2008-31.08.2009 } \\
\hline & $\bar{\rho}$ & $\alpha$ & $\beta$ & $v$ \\
\hline Gold & 0.065954 & 0.089203 & 0.831253 & 7.887173 \\
\hline Silver & 0.044743 & - & - & 8.496740 \\
\hline USD Index & -0.293293 & - & - & 15.649143 \\
\hline SwissFr Index & -0.052294 & - & - & 5.660732 \\
\hline Soybean & 0.379889 & - & - & 5.999898 \\
\hline \multirow[t]{3}{*}{ Corn } & 0.374819 & - & - & 14.214340 \\
\hline & \multicolumn{4}{|c|}{$03.02 .2020-31.03 .2021$} \\
\hline & $\bar{\rho}$ & $\alpha$ & $\beta$ & $v$ \\
\hline Gold & 0.010914 & 0.001337 & 0.873349 & 4.940858 \\
\hline Silver & 0.114382 & 0.026691 & 0.860876 & 4.278054 \\
\hline USD Index & \multicolumn{4}{|r|}{ no model } \\
\hline SwissFr Index & 0.196310 & 0.205921 & 0.793777 & 2.288835 \\
\hline Soybean & 0.035991 & 0.061127 & 0.824622 & 5.199916 \\
\hline Corn & 0.059974 & 0.026086 & 0.915480 & 5.785158 \\
\hline
\end{tabular}

Source: own calculations.

Table 2 presents the parameters of the DCC and CCC models of pairwise synchronized return data of the chosen instrument and stock exchange index from Germany for the considered periods. It can observed that if one considers the whole sample, the USD Index (the bold number of $\bar{\rho}$ ) can be identified as a safe haven instrument. When estimating the CCC model, one only obtained the values of $\bar{\rho}$ and $v$. The bold number of $\bar{\rho}$ means that this instrument can be considered as a safe haven for the considered financial market. One can observe such results of estimation for the GFC subsample. For that period, gold, silver, the USD Index, and the Swiss Franc Index can be identified as safe haven instruments. For the COVID-19 pandemic 
subsample, it can be observed that gold, soybean, corn can be identified as safe haven instruments. Moreover, there where changes in safe haven instruments between the GFC and the COVID-19 pandemic. Parameter $v$ is the Student-t degrees of freedom, which is also highly significant for all the considered markets.

Table 3. The parameters of the DCC and CCC models of pairwise synchronized return data of the chosen instrument and stock exchange index from Great Britain for the considered periods. Robust standard errors are available upon request

\begin{tabular}{|c|c|c|c|c|}
\hline \multirow{2}{*}{ FTSE 250} & \multicolumn{4}{|c|}{$01.01 .2007-31.03 .2021$} \\
\hline & $\bar{\rho}$ & $\alpha$ & $\beta$ & $v$ \\
\hline Gold & 0.516413 & 0.307105 & 0.692380 & 22.115887 \\
\hline Silver & 0.287231 & 0.330077 & 0.669102 & 20.831520 \\
\hline USD Index & -0.527038 & 0.274361 & 0.725346 & 39.155642 \\
\hline SwissFr Index & 0.882878 & 0.310123 & 0.687677 & 25.110362 \\
\hline Soybean & 0.590003 & 0.322644 & 0.676480 & 21.556808 \\
\hline \multirow[t]{3}{*}{ Corn } & 0.496611 & 0.323081 & 0.675611 & 20.881902 \\
\hline & \multicolumn{4}{|c|}{ 01.09.2008-31.08.2009 } \\
\hline & $\bar{\rho}$ & $\alpha$ & $\beta$ & $v$ \\
\hline Gold & 0.142721 & 0.090877 & 0.868059 & 14.871908 \\
\hline Silver & 0.185677 & 0.037537 & 0.928268 & 17.868146 \\
\hline USD Index & -0.255546 & - & - & 39.468108 \\
\hline SwissFr Index & -0.072539 & - & - & 8.761861 \\
\hline Soybean & 0.391215 & 0.007045 & 0.956976 & 8.878211 \\
\hline \multirow[t]{3}{*}{ Corn } & 0.386217 & - & - & 69.639579 \\
\hline & \multicolumn{4}{|c|}{$03.02 .2020-31.03 .2021$} \\
\hline & $\bar{\rho}$ & $\alpha$ & $\beta$ & $v$ \\
\hline Gold & \multicolumn{4}{|c|}{ no model } \\
\hline Silver & 0.208320 & 0.006344 & 0.954870 & 4.840090 \\
\hline USD Index & \multicolumn{4}{|r|}{ no model } \\
\hline SwissFr Index & 0.902774 & 0.541756 & 0.458009 & 2.411919 \\
\hline Soybean & 0.070960 & 0.020233 & 0.951973 & 6.508704 \\
\hline Corn & 0.153586 & 0.032465 & 0.947840 & 7.669558 \\
\hline
\end{tabular}

Source: own calculations.

Table 3 presents the parameters of the DCC and CCC models of pairwise synchronised return data of the chosen instrument and stock exchange index from Great Britain for the considered periods. One can observe that for the whole sample, the USD Index can be identified as a safe haven instrument. For the GFC subsample, the USD Index and the Swiss Franc Index can be identified as safe haven instruments. For those instruments, the study could obtain only the parameters of the CCC model. For the COVID-19 subsample, the study could not estimate the parameters model for gold and the USD Index. Only soybean could be considered as a safe haven instrument.

Table 4 presents the parameters of the DCC and CCC models of pairwise synchronised return data of chosen the instrument and stock exchange index from 
France for the considered periods. One can observe that for the whole sample all the considered instruments can be identified as safe haven instruments. For the GFC subsample, gold, silver, the USD Index, and the Swiss Franc Index can be identified as safe haven instruments. Moreover, for the USD Index and the Swiss Franc Index, the author could only estimate the parameters of the CCC model. For the COVID-19 pandemic subsample, gold, silver, the USD Index, and soybean can be identified as safe haven instruments. For the Swiss Franc Index, the study could not estimate any model. The parameters were non-essentials.

Table 4. The parameters of the DCC and CCC models of pairwise synchronised return data of the chosen instrument and stock exchange index from France for the considered periods. Robust standard errors are available upon request

\begin{tabular}{|c|c|c|c|c|}
\hline \multirow{2}{*}{ CAC 40} & \multicolumn{4}{|c|}{$01.01 .2007-31.03 .2021$} \\
\hline & $\bar{\rho}$ & $\alpha$ & $\beta$ & $v$ \\
\hline Gold & -0.111693 & 0.289752 & 0.709913 & 23.967039 \\
\hline Silver & -0.328587 & 0.280473 & 0.718929 & 27.756065 \\
\hline USD Index & -0.382487 & 0.256510 & 0.743180 & 50.794620 \\
\hline SwissFr Index & -0.634752 & 0.267325 & 0.732454 & 29.073067 \\
\hline Soybean & -0.495371 & 0.335839 & 0.662225 & 25.124020 \\
\hline \multirow[t]{3}{*}{ Corn } & -0.589468 & 0.303219 & 0.695152 & 23.886229 \\
\hline & \multicolumn{4}{|c|}{$01.09 .2008-31.08 .2009$} \\
\hline & $\bar{\rho}$ & $\alpha$ & $\beta$ & $v$ \\
\hline Gold & 0.072893 & 0.094568 & 0.831177 & 8.284136 \\
\hline Silver & 0.087991 & 0.016716 & 0.924715 & 8.787917 \\
\hline USD Index & -0.291051 & - & - & 15.227042 \\
\hline SwissFr Index & -0.061184 & - & - & 5.999928 \\
\hline Soybean & 0.408178 & 0.011841 & 0.950488 & 6.686418 \\
\hline \multirow[t]{3}{*}{ Corn } & 0.380423 & 0.008356 & 0.964772 & 15.769578 \\
\hline & \multicolumn{4}{|c|}{ 03.02.2020-31.03.2021 } \\
\hline & $\bar{\rho}$ & $\alpha$ & $\beta$ & $v$ \\
\hline Gold & -0.061977 & 0.0000001 & 0.630948 & 5.023196 \\
\hline Silver & 0.084791 & 0.041560 & 0.859521 & 3.922632 \\
\hline USD Index & -0.091411 & 0.029066 & 0.500201 & 8.070789 \\
\hline SwissFr Index & \multicolumn{4}{|c|}{ no model } \\
\hline Soybean & 0.080930 & 0.033181 & 0.922228 & 5.659776 \\
\hline Corn & 0.130967 & 0.042199 & 0.931961 & 6.133494 \\
\hline
\end{tabular}

Source: own calculations.

Table 5 presents the parameters of the DCC and CCC models of pairwise synchronised return data of the chosen instrument and stock exchange index from Spain for the considered periods. One can observe that for the whole sample all the considered instruments can be identified as safe haven instruments. The study could only estimate the parameters of the CCC model. For the GFC subsample, gold, silver, the USD Index, and the Swiss Franc Index can be considered as safe haven 
instruments. For the USD Index, the Swiss Franc Index, soybean and corn, the author could only estimate the CCC model parameters. For the COVID-19 pandemic subsample, only the Swiss Franc Index cannot be considered as a safe haven instrument. For gold and the USD Index the study obtained the CCC model parameters.

Table 5. The parameters of the DCC and CCC models of pairwise synchronised return data of the chosen instrument and stock exchange index from Spain for the considered periods. Robust standard errors are available upon request

\begin{tabular}{|c|c|c|c|c|}
\hline \multirow{2}{*}{ IBEX 35} & \multicolumn{4}{|c|}{$01.01 .2007-31.03 .2021$} \\
\hline & $\bar{\rho}$ & $\alpha$ & $\beta$ & $v$ \\
\hline Gold & -0.003252 & - & - & 92.753053 \\
\hline Silver & 0.001710 & - & - & 104.355424 \\
\hline USD Index & 0.015681 & - & - & 159.459842 \\
\hline SwissFr Index & 0.002405 & - & - & 125.366908 \\
\hline Soybean & -0.002724 & - & - & 84.238137 \\
\hline \multirow[t]{3}{*}{ Corn } & -0.019103 & - & - & 66.386719 \\
\hline & \multicolumn{4}{|c|}{ 01.09.2008-31.08.2009 } \\
\hline & $\bar{\rho}$ & $\alpha$ & $\beta$ & $v$ \\
\hline Gold & 0.039751 & 0.091764 & 0.849756 & 10.751785 \\
\hline Silver & $\mathbf{0 . 0 7 3 1 3 6}$ & 0.027959 & 0.915576 & 12.184039 \\
\hline USD Index & -0.294884 & - & - & 25.996181 \\
\hline SwissFr Index & -0.079944 & - & - & 6.996398 \\
\hline Soybean & 0.380609 & - & - & 7.109211 \\
\hline \multirow[t]{3}{*}{ Corn } & 0.369003 & - & - & 26.334174 \\
\hline & \multicolumn{4}{|c|}{$03.02 .2020-31.03 .2021$} \\
\hline & $\bar{\rho}$ & $\alpha$ & $\beta$ & $v$ \\
\hline Gold & $-\mathbf{0 . 0 3 7 8 1 7}$ & - & - & 5.590900 \\
\hline Silver & $\mathbf{0 . 0 9 6 5 3 8}$ & 0.030079 & 0.882070 & 4.391082 \\
\hline USD Index & -0.109094 & - & - & 9.940436 \\
\hline SwissFr Index & 0.409208 & 0.285351 & 0.714413 & 2.345541 \\
\hline Soybean & 0.010224 & 0.028799 & 0.948437 & 6.108007 \\
\hline Corn & 0.087124 & 0.043335 & 0.937333 & 7.166026 \\
\hline
\end{tabular}

Source: own calculations.

Table 6 presents the parameters of the DCC and CCC models of pairwise synchronised return data of the chosen instrument and stock exchange index from Italy for the considered periods. One can observe that for the whole sample all the instruments can be considered as a safe haven. For that period, the essentials were the parameters of the DCC-IGARCH and DCC-GJR (for silver) models. For the GFC subsample, gold and the Swiss Franc Index can be identified as safe haven instruments. For the USD Index, the author could not obtain the essential parameters of any model. For the COVID-19 pandemic subsample, gold, the USD Index, and soybean can be 
identified as safe haven instruments. For gold and the USD Index it was possible to obtain the CCC model parameters.

Table 6. The parameters of the DCC and CCC models of pairwise synchronised return data of the chosen instrument and stock exchange index from Italy for the considered periods. Robust standard errors are available upon request

\begin{tabular}{|c|c|c|c|c|}
\hline \multirow{2}{*}{ FTSE IMB } & \multicolumn{4}{|c|}{$01.01 .2007-31.03 .2021$} \\
\hline & $\bar{\rho}$ & $\alpha$ & $\beta$ & $v$ \\
\hline Gold & -0.905459 & 0.313474 & 0.685111 & 20.714690 \\
\hline Silver & $-0.756582 *$ & 0.365967 & 0.631163 & 20.397730 \\
\hline USD Index & -0.072280 & 0.348577 & 0.649803 & 20.068708 \\
\hline SwissFr Index & -0.925481 & 0.293203 & 0.706160 & 18.527786 \\
\hline Soybean & -0.450040 & 0.339938 & 0.658690 & 21.277529 \\
\hline \multirow[t]{3}{*}{ Corn } & -0.468726 & 0.318126 & 0.680777 & 21.647921 \\
\hline & \multicolumn{4}{|c|}{ 01.09.2008-31.08.2009 } \\
\hline & $\bar{\rho}$ & $\alpha$ & $\beta$ & $v$ \\
\hline Gold & 0.087857 & 0.626057 & 0.298057 & 341.248745 \\
\hline Silver & 0.146045 & 0.820584 & 0.025565 & 341.248749 \\
\hline USD Index & \multicolumn{4}{|c|}{ No model } \\
\hline SwissFr Index & -0.292304 & 0.597082 & 0.231977 & 118.929247 \\
\hline Soybean & 0.271237 & - & - & 341.248733 \\
\hline \multirow[t]{3}{*}{ Corn } & 0.537148 & 0.502772 & 0.446010 & 341.247871 \\
\hline & \multicolumn{4}{|c|}{ 03.02.2020-31.03.2021 } \\
\hline & $\bar{\rho}$ & $\alpha$ & $\beta$ & $v$ \\
\hline Gold & -0.000296 & - & - & 4.732137 \\
\hline Silver & 0.195548 & 0.008773 & 0.921560 & 4.042324 \\
\hline USD Index & -0.134967 & - & - & 7.535584 \\
\hline SwissFr Index & 0.347140 & 0.266768 & 0.733009 & 2.275620 \\
\hline Soybean & 0.057202 & 0.018392 & 0.954323 & 5.224603 \\
\hline Corn & 0.102953 & 0.023381 & 0.947635 & 5.454724 \\
\hline
\end{tabular}

* Model GJR is represented by the blue numbers, the green numbers are for the IGARCH model. Source: own calculations.

Table 7 presents the parameters of the DCC and CCC models of pairwise synchronised return data of the chosen instrument and stock exchange index from Poland for the considered periods. One can observe that for the whole sample, silver, soybean, and corn can be considered as safe haven instruments. For the Swiss Franc Index, the author was able to estimate the CCC model parameters. For the GFC subsample all the considered instruments can be identified as safe haven instruments. For gold, silver, and the Swiss Franc Index, the study could obtain the CCC model parameters. For the COVID-19 pandemic subsample, gold, the USD Index, soybean, and corn can be identified as safe haven instruments. One could observe the changes 
in safe haven instruments if the GFC period and COVID-19 pandemic subsample were considered.

Table 7. The parameters of the DCC and CCC models of pairwise synchronised return data of the chosen instrument and stock exchange index from Poland for the considered periods. Robust standard errors are available upon request

\begin{tabular}{|c|c|c|c|c|}
\hline \multirow{2}{*}{ WIG } & \multicolumn{4}{|c|}{$01.01 .2007-31.03 .2021$} \\
\hline & $\bar{\rho}$ & $\alpha$ & $\beta$ & $v$ \\
\hline Gold & 0.288376 & 0.312920 & 0.684106 & 324.609563 \\
\hline Silver & -0.190891 & 0.419069 & 0.573752 & 227.282676 \\
\hline USD Index & 0.413558 & 0.281966 & 0.714879 & 341.248749 \\
\hline SwissFr Index & 0.507404 & - & - & 341.248749 \\
\hline Soybean & -0.334979 & 0.469996 & 0.519240 & 197.175040 \\
\hline \multirow[t]{3}{*}{ Corn } & -0.164527 & 0.335086 & 0.661541 & 341.248749 \\
\hline & \multicolumn{4}{|c|}{ 01.09.2008-31.08.2009 } \\
\hline & $\bar{\rho}$ & $\alpha$ & $\beta$ & $v$ \\
\hline Gold & -0.056884 & - & - & 8.440039 \\
\hline Silver & 0.001867 & - & - & 10.315535 \\
\hline USD Index & -0.057076 & 0.039719 & 0.910702 & 19.703132 \\
\hline SwissFr Index & 0.020360 & - & - & 6.900238 \\
\hline Soybean & 0.019901 & 0.019414 & 0.930593 & 6.217298 \\
\hline \multirow[t]{3}{*}{ Corn } & 0.020712 & 0.039603 & 0.899605 & 9.072848 \\
\hline & \multicolumn{4}{|c|}{$03.02 .2020-31.03 .2021$} \\
\hline & $\bar{\rho}$ & A & $\beta$ & $v$ \\
\hline Gold & 0.090595 & - & - & 6.571531 \\
\hline Silver & 0.140441 & - & - & 4.838727 \\
\hline USD Index & -0.139925 & - & - & 13.640336 \\
\hline SwissFr Index & 0.243537 & 0.212795 & 0.786945 & 2.354907 \\
\hline Soybean & 0.070992 & 0.011588 & 0.804939 & 6.995422 \\
\hline Corn & 0.080587 & 0.032237 & 0.657619 & 7.453202 \\
\hline
\end{tabular}

Source: own calculations.

Table 8 presents a static correlation between the considered instruments for the whole period from 01.01.2007 until 31.03.2021. This only confirms that gold, the USD Index, and the Swiss Franc Index can be identified as safe haven instruments, for which the correlation coefficient is negative (the bold numbers).

Table 9 presents a static correlation between the considered instruments for the Global Financial Crisis subsample from 01.09.2008 until 31.08.2009. One can observe that gold, the USD Index, and the Swiss Franc Index can be identified as safe haven instruments. 
Table 8. Static correlation between the considered instruments for the period 01.01.2007-31.03.2021

\begin{tabular}{|l|c|c|c|c|c|c|}
\hline $\begin{array}{l}\text { 01.01.2007- } \\
-31.03 .2021\end{array}$ & GOLD & SILVER & $\begin{array}{c}\text { USD } \\
\text { INDEX }\end{array}$ & $\begin{array}{c}\text { SWISSFR } \\
\text { INDEX }\end{array}$ & SOYBEAN & CORN \\
\hline SILVER & 0.6975 & 1.0000 & $\mathbf{- 0 . 2 2 0 1}$ & 0.0763 & 0.1225 & 0.0901 \\
\hline USD INDEX & $\mathbf{- 0 . 2 2 2 1}$ & $\mathbf{- 0 . 2 2 0 1}$ & 1.0000 & $-\mathbf{0 . 2 9 2 7}$ & $-\mathbf{0 . 1 7 1 3}$ & $-\mathbf{0 . 1 4 9 9}$ \\
\hline $\begin{array}{l}\text { SWISSFR } \\
\text { INDEX }\end{array}$ & 0.1117 & 0.0763 & $\mathbf{- 0 . 2 9 2 7}$ & 1.0000 & 0.0139 & 0.0254 \\
\hline SOYBEAN & 0.0706 & 0.1225 & $\mathbf{- 0 . 1 7 1 3}$ & 0.0139 & 1.0000 & 0.5082 \\
\hline CORN & 0.0693 & 0.0901 & $\mathbf{- 0 . 1 4 9 9}$ & 0.0254 & 0.5082 & 1.0000 \\
\hline DAX & $\mathbf{- 0 . 0 5 0 9}$ & 0.0941 & $\mathbf{- 0 . 1 6 1 9}$ & $\mathbf{- 0 . 0 5 7 2}$ & 0.2064 & 0.1521 \\
\hline FTSE250 & $\mathbf{- 0 . 0 0 3 1}$ & 0.1486 & $\mathbf{- 0 . 1 5 4 4}$ & $\mathbf{- 0 . 0 4 6 2}$ & 0.2135 & 0.1519 \\
\hline CAC40 & $\mathbf{- 0 . 0 7 2 6}$ & 0.0879 & $\mathbf{- 0 . 1 6 1 5}$ & $\mathbf{- 0 . 0 4 7 8}$ & 0.2234 & 0.1690 \\
\hline IBEX35 & $\mathbf{- 0 . 0 8 0 7}$ & 0.0553 & $\mathbf{- 0 . 1 8 6 4}$ & $\mathbf{- 0 . 0 4 3 4}$ & 0.1918 & 0.1423 \\
\hline FTSE MIB & $\mathbf{- 0 . 0 8 2 7}$ & 0.0612 & $-\mathbf{0 . 1 7 9 0}$ & $\mathbf{- 0 . 0 4 3 2}$ & 0.2118 & 0.1556 \\
\hline WIG & 0.0191 & 0.0487 & $\mathbf{- 0 . 0 7 0 1}$ & $\mathbf{0 . 0 0 1 2}$ & 0.0777 & 0.0252 \\
\hline
\end{tabular}

Source: own calculations.

Table 9. Static correlation between the considered instruments for the period 01.09.2008-31.08.2009

\begin{tabular}{|l|c|c|c|c|c|c|}
\hline $\begin{array}{c}\text { 01.09.2008- } \\
-31.08 .2009\end{array}$ & GOLD & SILVER & $\begin{array}{c}\text { USD } \\
\text { INDEX }\end{array}$ & $\begin{array}{c}\text { SWISSFR } \\
\text { INDEX }\end{array}$ & SOYBEAN & CORN \\
\hline SILVER & 0.7382 & 1.0000 & $\mathbf{- 0 . 2 7 7 1}$ & 0.1220 & 0.1897 & 0.2158 \\
\hline USD INDEX & $\mathbf{- 0 . 2 9 4 4}$ & $\mathbf{- 0 . 2 7 7 1}$ & 1.0000 & $\mathbf{- 0 . 3 5 5 9}$ & $\mathbf{- 0 . 3 6 2 0}$ & $-\mathbf{0 . 3 8 7 7}$ \\
\hline $\begin{array}{l}\text { SWISSFR } \\
\text { INDEX }\end{array}$ & 0.1736 & 0.1220 & $\mathbf{- 0 . 3 5 5 9}$ & 1.0000 & 0.0151 & 0.0590 \\
\hline SOYBEAN & 0.0857 & 0.1897 & $\mathbf{- 0 . 3 6 2 0}$ & 0.0151 & 1.0000 & 0.6828 \\
\hline CORN & 0.1274 & 0.2158 & $\mathbf{- 0 . 3 8 7 7}$ & 0.0590 & 0.6828 & 1.0000 \\
\hline DAX & $\mathbf{- 0 . 1 2 0 2}$ & 0.0093 & $\mathbf{- 0 . 3 1 8 7}$ & $\mathbf{- 0 . 0 6 8 3}$ & 0.3770 & 0.4203 \\
\hline FTSE250 & $\mathbf{- 0 . 0 6 1 8}$ & 0.1430 & $\mathbf{- 0 . 2 8 9 2}$ & $\mathbf{- 0 . 0 8 8 7}$ & 0.4190 & 0.4277 \\
\hline CAC40 & $\mathbf{- 0 . 1 4 9 1}$ & 0.0616 & $\mathbf{- 0 . 3 2 7 3}$ & $\mathbf{- 0 . 0 6 5 4}$ & 0.4500 & 0.4640 \\
\hline IBEX35 & $\mathbf{- 0 . 1 3 2 2}$ & 0.0234 & $\mathbf{- 0 . 3 4 5 1}$ & $\mathbf{- 0 . 0 9 5 3}$ & 0.4142 & 0.4190 \\
\hline FTSE MIB & $\mathbf{- 0 . 1 6 2 7}$ & 0.0445 & $\mathbf{- 0 . 3 3 8 3}$ & $\mathbf{- 0 . 0 9 5 6}$ & 0.4321 & 0.4449 \\
\hline WIG & $\mathbf{- 0 . 0 0 9 0}$ & 0.0407 & $\mathbf{- 0 . 1 7 3 0}$ & 0.0198 & 0.1576 & 0.1230 \\
\hline
\end{tabular}

Source: own calculations.

Table 10 presents a static correlation between the considered instruments for the COVID-19 pandemic subsample from 03.02.2020 until 31.03.2021. One can observe that the USD Index and the Swiss Franc Index can be identified as safe haven instruments. Surprisingly, for investors from France, Italy, and Spain, only gold can be considered a safe haven instrument. 
Table 10. Static correlation between the considered instruments for the period 03.02.2020-31.03.2021

\begin{tabular}{|l|c|c|c|c|c|c|}
\hline $\begin{array}{l}\text { 03.02.2020- } \\
-31.03 .2021\end{array}$ & GOLD & SILVER & $\begin{array}{c}\text { USD } \\
\text { INDEX }\end{array}$ & $\begin{array}{c}\text { SWISSFR } \\
\text { INDEX }\end{array}$ & SOYBEAN & CORN \\
\hline SILVER & 0.5553 & 1.0000 & $\mathbf{- 0 . 2 5 5 2}$ & $\mathbf{- 0 . 0 2 2 5}$ & 0.1599 & 0.1874 \\
\hline USD INDEX & $\mathbf{- 0 . 3 2 3 4}$ & $\mathbf{- 0 . 2 5 5 2}$ & 1.0000 & $\mathbf{- 0 . 1 2 1 3}$ & $\mathbf{- 0 . 0 5 7 6}$ & $\mathbf{- 0 . 0 9 3 2}$ \\
\hline $\begin{array}{l}\text { SWISSFR } \\
\text { INDEX }\end{array}$ & 0.0100 & $\mathbf{- 0 . 0 2 2 5}$ & $\mathbf{- 0 . 1 2 1 3}$ & 1.0000 & $\mathbf{- 0 . 0 8 6 8}$ & 0.0109 \\
\hline SOYBEAN & 0.0365 & 0.1599 & $\mathbf{- 0 . 0 5 7 6}$ & $\mathbf{- 0 . 0 8 6 8}$ & 1.0000 & 0.7249 \\
\hline CORN & 0.0669 & 0.1874 & $\mathbf{- 0 . 0 9 3 2}$ & 0.0109 & 0.7249 & 1.0000 \\
\hline DAX & 0.0856 & 0.2615 & $\mathbf{- 0 . 2 0 0 4}$ & $\mathbf{- 0 . 1 1 4 5}$ & 0.1827 & 0.1460 \\
\hline FTSE250 & 0.0968 & 0.2956 & $\mathbf{- 0 . 2 2 7 1}$ & $\mathbf{- 0 . 0 8 2 7}$ & 0.1573 & 0.2048 \\
\hline CAC40 & $\mathbf{- 0 . 0 5 4 7}$ & 0.2201 & $\mathbf{- 0 . 0 9 7 4}$ & $\mathbf{- 0 . 1 0 2 8}$ & 0.2173 & 0.1963 \\
\hline IBEX35 & $\mathbf{- 0 . 0 5 1 4}$ & 0.1804 & $\mathbf{- 0 . 0 6 6 5}$ & $\mathbf{- 0 . 0 9 9 6}$ & 0.1783 & 0.1579 \\
\hline FTSE MIB & $\mathbf{- 0 . 0 1 8 7}$ & 0.2192 & $\mathbf{- 0 . 0 7 3 8}$ & $\mathbf{- 0 . 0 9 5 9}$ & 0.2025 & 0.1910 \\
\hline WIG & 0.1416 & 0.1967 & $\mathbf{- 0 . 1 6 9 5}$ & $\mathbf{- 0 . 0 5 0 2}$ & 0.1325 & 0.0792 \\
\hline
\end{tabular}

Source: own calculations.

\section{Conclusions}

Searching for safe haven instruments is an important issue during market turmoil. This paper examined the performance of gold, silver, the USD Index, the Swiss Franc Index, soybean, and corn, as safe haven assets from stock market losses of European economies during the Global Financial Crisis and the COVID-19 pandemic. The results showed that only gold could protect investors from stock market losses during both crises. During the GFC, gold, the USD Index, and the Swiss Franc Index in almost all the considered countries could be identified as safe haven instruments.

Surprisingly, the Swiss Franc Index acted as a safe haven instrument during the GFC but not during the COVID-19 pandemic. Soybean acted as a safe haven instrument during the COVID-19 pandemic in all six countries, but only in Poland during the GFC.

The study's findings are in line with the literature stating that safe haven instruments can change over time and across countries. Moreover, when searching for safe haven instruments, one have to remember that the COVID-19 pandemic crisis differ from the Global Financial Crisis in their fundamental characteristics of market turmoil.

These findings are useful for investors and fund managers searching for safe haven instruments. Further research might be carried out to identify other safe haven instruments during the COVID-19 pandemic. 


\section{References}

Al-Awadhi, A. M., Al-Saifi, K., Al-Awadhi, A., and Alhamadi, S. (2020). Death and contagious infectious diseases: Impact of the COVID-19 virus on stock market returns. Journal of Behavioral and Experimental Finance, (27). Retrieved from https://doi.org/10.1016/j.jbef.2020.100326

Baker, S. R., Bloom, N., Davis, S. J., Kost, K., Sammon, M., and Viratyosin, T. (2020). The unprecedented stock market reaction to COVID-19. Covid Economics, 1(3), 33-42.

Baur, D. G., and Lucey, B. M. (2010). Is gold a hedge or a safe-haven? An analysis of stocks, bonds and gold. Financial Review, (45), 217-229.

Baur, D. G., and McDermott, T. K. (2010). Is gold a safe haven? International evidence. Journal of Banking \& Finance, (34), 1886-1898.

Beckmann, J., Berger, T., and Czudaj, R. (2015). Does gold act as a hedge or a safe-haven for stocks? A smooth transition approach. Economic Modelling, (48), 16-24.

Bloomberg. (2020). Perfect storm plunges Asia stocks into bear markets one by one.

Bouri, E., Shahzad, S., Roubaud, D., Kristoufek, L., and Lucey, B. (2020). Bitcoin, gold, and commodities as safe havens for stocks: New insight through wavelet analysis. The Quarterly Review of Economics and Finance. Retrieved from https://doi.org/10.1016/j.qref.2020.03. 004

Corbet, S., Larkin, C., and Lucey, B. (2020). The contagion effects of the Covid-19 pandemic: evidence from gold and cryptocurrencies. Finance Research Letters. Retrieved from https://doi.org/10.1016j.frl.2020. 101554

Engle, R. F. (2002). Dynamic conditional correlation: A simple class of multivariate generalized autoregressive conditional heteroskedasticity models. Journal of Business \& Economic Statistics, (20), 339.

Goodwell, J. W. (2020). COVID-19 and finance: Agendas for future research. Finance Research Letters, 101512. Retrieved from https://doi.org/10.1016/j.frl.2020.101512

Grisse, C., and Nitschka, T. (2015). On financial risk and the safe-haven characteristics of Swiss Franc exchange rates. Journal of Empirical Finance, (32), 153-164.

Hillier, D., Draper, P., and Faff, R. (2006). Do precious metals shine? An investment perspective. Financial Analysts Journal, (62), 98-106.

Hood, M., and Malik, F. (2013). Is gold the best hedge and a safe-haven under changing stock market volatility? Review of Financial Economics, (22), 47-52.

Lucey, B. M., and Li, S. (2015). What precious metals act as safe havens, and when? Some US evidence. Applied Economics Letters, 22(1), 35-45.

Kaul, A., and Sapp, S. (2006). Y2K fears and safe haven trading of the US dollar. Journal of International Money and Finance, (25), 760-779.

Nakatani, T., and Teräsvirta, T. (2009) Appendix to testing for volatility interactions in the constant conditional correlation GARCH model. Department of Economic Statistics, Stockholm School of Economics.

Pullen, T., Benson, K., and Faff, R. (2014). A comparative analysis of the investment characteristics of alternative gold assets. Abacus, (50), 76-92.

Ramelli, S., and Wagner, A. F. (2020). Feverish stock price reactions to Covid-19.

Ranaldo, A., and Söderlind, P. (2010). Safe haven currencies, review of finance. European Finance Association, 14(3), 385-407.

The Guardian. (2020). FTSE 100 suffers worst quarter since 1987 as Covid-19 recession looms - as it happened.

Wu, F., Zhao, W., Ji, Q., and Zhang, D. (2020). Dependency, centrality and dynamic networks for international commodity futures prices. International Review of Economics and Finance, (67), 118-132.

Xia, T., Ji, Q., Zhang, D., and Han, J. (2019). Asymmetric and extreme influence of energy price changes on renewable energy stock performance. Journal of Cleaner Production, (241), 118338.

Zhang, D., Hu, M., and Ji, Q. (2020). Financial markets under the global pandemic of COVID-19. Finance Research Letters. Retrieved from https://doi.org/10.1016/j.frl.2020.101528 


\section{INSTRUMENTY SAFE HAVEN - PORÓWNANIE MIĘDZY GLOBALNYM KRYZYSEM FINANSOWYM A PANDEMIĄ COVID-19}

Streszczenie: Podczas globalnego kryzysu finansowego i pandemii COVID-19 rynki finansowe zanotowały najniższe wartości indeksów giełdowych. Należy pamiętać, że aktualny kryzys różni się od globalnego kryzysu finansowego. W artykule porównano dynamikę instrumentów safe haven podczas globalnego kryzysu finansowego oraz pandemii COVID-19. Przeanalizowano dynamiczną relację między złotem, srebrem, indeksami US Dollar, Swiss franc, kontraktami terminowymi na soję i kukurydzę oraz rynkami giełdowymi dla inwestorów z Niemiec, Wielkiej Brytanii, Francji, Hiszpani, Włoch oraz Polski. Wyestymowano parametry modelów DCC albo CCC, by porównać dynamiczną relację między wspomnianymi rynkami giełdowymi i instrumentami finansowymi. Wyniki pokazują, że jedynie złoto może być traktowane jako instrument safe haven podczas obu rozważanych kryzysów. Podczas globalnego kryzysu finansowego złoto, indeksy US Dollar i Swiss franc w prawie wszystkich krajach zidentyfikowano jako instrument safe haven.

Słowa kluczowe: instrumenty safe haven, globalny kryzys finansowy, pandemia COVID-19, złoto, dynamiczna korelacja. 